Milium pungens of Torrey. Asplenium melanocaulon closely re. sembling our $A$. trichomanes occurred here, and at several other places in crevices of the rocks.

Kingston Mills, the last station on the canal to which I referred, was not examined at all at this time, but as during a subsequent residence at Kingston in 1845-6, I had frequent opportunities of collecting in that neighbourhood, I mention the more interesting results here to render the account of the district more complete. At Kingston Mills the canal is carried through a deep glen, surrounded by rounded hills of granite protruding through the limestone strata, and then unites with the Cataragui river, a broad, sluggish stream with extensive marshy banks which bear a profusion of Acorus Calamus.

On one of the southern declivities of the granite with a very scanty covering of soil, the Corydalis glauca reappears in great profusion and beauty, accompanied by Silene antirrhina, Aspidium rufidulum and Polygonum cilinode, a remarkable species sending long runners to a distance of ten or twelve feet over the rocks. Arabis hirsuta, Lepidium ruderale and Turritis stricta were found more sparingly in the same situation. In the damp valley itself, among the under brush composed of Lonicera and Ribes prostratum, Cornus canadensis with Anoplon biflorum made their appearance. The latter, the Orobanche uniflora of older authors, occurs very sparingly; and of another uncommon species, the Ranunculus fascicularis, I only observed one small patch.

From this catalogue it will be observed that the vegetation of this district (which lies in about $76^{\circ} \mathrm{W}$. longitude and between $44^{\circ}$ and $45^{\circ} \mathrm{N}$. lat.) resembles much more that of the lower or eastern than of the upper section of the province; and the rarity as well as the poor appearance of the Podophyllum peltatum and Zanthoxylon americanum, when they do occur-species abundant in Western Canada-show that they nearly reach their northern and eastern limit at the Rideau Canal.

IV.-Description of two new species of Carabus from Asia. By T. Tatum, Esq.

\title{
Carabus lithariophorus.
}

Entirely of a bright jet-black. Head rather large and smooth, with two deep indentations between the antennæ. Palpi with the extreme joints strongly securiform. Antenna long and tapering, the last seven joints of a rusty brown colour. Thorax broad, rather flat and smooth except near the lateral and posterior mar- 
gins, where it is thickly marked with punctures ; the median furrow strongly defined; the edges slightly elevated; anterior and posterior margins square; sides convex before, concave behind, giving a somewhat heart-shape to the thorax ; anterior angles rounded; posterior acute and slightly produced outwards as well as backwards, giving considerable width to the posterior part of the thorax. Elytra oval, convex, tapering towards the base as well as the extremity; on each, three longitudinal rows of elevated oval tubercles; occasionally two or three run into one another, producing a continuous ridge; the rows of tubercles are separated from each other, from the suture and from the external margin, by treble rows of small elevations or granules of various sizes. Length 1 inch $5 \frac{3}{4}$ lines.

$H a b$. Mussoorie in the Himalayas. In coll. of Brit. Mus. and T. Tatum.

The general aspect of this Carabus is like a Procrustes: the sculpture on the elytra resembles that of the Carabus Lafossei described by the Baron Feisthamel in the 'Ann. Soc. Ent. France,' 2nd series, p. 103. t. 2 . f. $1 \& 2$.

\section{Carabus monilifer}

somewhat resembles the preceding species in size, form and sculpture of the elytra. The head is smaller and studded with minute punctures. Thorax much smaller, its anterior and posterior margins slightly concave; sides less sinuous, and posterior angles less produced; margins slightly elevated; the surface like the head finely punctured, convex; median furrow obsolete, and on either side of this line, and near to posterior margin, a slightly elevated tubercle. Form of elytra as in the preceding species: the three rows of tubercles smaller, flatter, and more regular in size and form; between each row, and also near the suture and external margin, a single row of smaller tubercles, also more regular than in the former insect, and the entire spaces between the tubercles studded with punctures, giving a fine granulated appearance to those parts. The colour is a less decided black than C. lithariophorus, with slight tints of bronze, both on the thorax and on the margins of the elytra. Length 1 inch $3 \frac{1}{2}$ lines.

It was found by A. Adams, Esq., during the voyage of H.M.S. Samarang in the Eastern Seas, in the Corean Archipelago. In coll. of Brit. Mus. 


\section{$2 \mathrm{BHL}$ Biodiversity Heritage Library}

Tatum, T. 1847. "IV.-Description of two new species of Carabus from Asia." The Annals and magazine of natural history; zoology, botany, and geology 20, 14-15. https://doi.org/10.1080/037454809496004.

View This Item Online: https://www.biodiversitylibrary.org/item/19465

DOI: https://doi.org/10.1080/037454809496004

Permalink: https://www.biodiversitylibrary.org/partpdf/14186

\section{Holding Institution}

Natural History Museum Library, London

\section{Sponsored by}

Natural History Museum Library, London

\section{Copyright \& Reuse}

Copyright Status: Public domain. The BHL considers that this work is no longer under copyright protection.

This document was created from content at the Biodiversity Heritage Library, the world's largest open access digital library for biodiversity literature and archives. Visit BHL at https://www.biodiversitylibrary.org. 